\title{
The impact of inflation on the Libyan economy after the Arab Spring Revolution during the period (2011-2018)
}

\author{
AZA YOUSEF ALHASADI \\ DOI: $10.31364 / S C I R J / v 7 . i 4.2019 . P 0419634$ \\ http://dx.doi.org/10.31364/SCIRJ/v7.i4.2019.P0419634
}

\begin{abstract}
The study aims to identify the impact of inflation on the Libyan economy after the Arab Spring Revolution during the period (2011-2018). The study was collected between the descriptive and analytical method. The data of study based on the economic publications issued by the Central Bank of Libya. The study concluded that the Libyan economy is witnessing a rise in price levels due to a number of factors, the most important of which are the events that took place in Libya during the period (2011 - 2018). As the political turmoil in the country continues will lead to exacerbates the country's inflation crisis.
\end{abstract}

Keywords: Inflation, Consumer Price Index, The annual inflation rate, Libyan Economy.

\subsection{Introduction:}

Inflation is a part of the macroeconomic phenomenon that has preoccupied economists for a long period of time due to the effects of this phenomenon on the economy in general. The goal of combating inflation and maintaining price stability is still one of the basic objectives that governments seek to achieve that is considered an indicator of the failure or success of governments. There is a debate among economists on the study of inflation and its causes and effects because inflation itself is a macroeconomic phenomenon and dynamic at the same time, which means that there are many factors involved in the occurrence, and because of its dynamism is difficult to identify and measure factors affecting it an accurate degree. Therefore, Inflation is achieved when the increase in the goods and services becomes disproportionate to the volume of increase in payment instruments. So, the money instead of becoming intermediary for exchange and as a good store of value, it will become a tool for absorbing the real purchasing power of individuals. Most of the world's economies are suffering from inflation. In particular, the Libyan economy is one of the least diversified economies in the world. Where it depends mainly on the oil and gas sector, where the unrest in Libya in 2011 led to a sharp decline in oil production, that is considered the only source of income in the country, which in turn has caused economic growth to falter and the GDP where shrank by $80 \%$. The pressures on the Libyan economy are not limited to halting the production and export of oil but the continued decline in global crude oil prices has caused deficit in the general budget, which prompted Libya to the depletion of its reserves of foreign exchange, which caused the rise in prices and lower levels in the value of the Libyan dinar and the deterioration of its exchange against foreign currencies. Based on the above, the aim of this study is to identify the economic effects of this phenomenon and to try to identify the possible solutions adopted by the state to alleviate inflationary pressures.

\subsection{A problem of the study:}

The problem of the study revolves around the phenomenon of inflation, especially in the light of the events witnessed in Libya and the attempts of monetary and executive authorities to reduce the inflationary pressures. Therefore, the problem of the study lies in the following question:

What is the impact of inflation on the Libyan economy during the period (2011-2018)? 


\subsection{The hypothesis of the study:}

The treatment of inflation in Libya requires control by determining its nature, types, and causes, and choosing the best and most successful policies to alleviate the inflationary pressures in the Libyan economy. Therefore, the main hypothesis lies in the following:

H1: There is a very large impact of inflation on the Libyan economy.

\subsection{Objectives of the study:}

The study seeks to analyze the causes and sources of inflation in the Libyan economy during the period (2011-2018), as well as identify the most important effects of inflation on the Libyan economy.

\subsection{Importance of the study:}

The study derives its importance by determining the phenomenon of inflation and studying the factors and reasons that contributed to the creation of this phenomenon. And identify the effects of inflationary pressures on the Libyan economy.

\subsection{Limits of the study:}

1. Objective limits include determining the effects of inflation on the Libyan economy and identifying the mechanisms adopted by the government authorities to alleviate the inflationary pressures.

2 - The time limits are determining the effects of inflation on the Libyan economy during the period $2011-2018$.

\subsection{Methodology of the study:}

This study was based on an analytical descriptive approach that describes the problem and the objectives of the study. Where it relied on articles, periodicals and Internet sites to cover the theoretical side of the study. As for the analytical aspect, the study used economic reports issued by the Central Bank of Libya which were used to analyze and comment on the data.

To achieve the research objectives, the study will be divided into two aspects:

Theoretical side in this regard, we will highlight the concept of inflation, its measurement, its effects, and ways to combat it. The analytical side will include the study of inflation trends in the Libyan economy as well as the analysis of data and economic indicators issued by the Central Bank of Libya to track the effects of inflation on the Libyan economy during the period 2011 2018 .

\subsection{Literature review:}

There are numerous studies related to inflation-topics and ways of dealing with them, but they often revolve around monetary policy as the most important way to deal with inflation. Therefore, the most various previous studies that studied were not directly related to the subject but just related to one of its components. Thus, we find:

Al-Rubaie (2006) highlighted the reasons for the inflation phenomenon in Iraq and addressed the concept of inflation, and its economic effects, and the most important factors that contributed to the increase the inflation in the Iraqi economy. The study concluded that successive transitional governments faced failures in many areas that contributed to the intensification of the phenomenon of inflation, notably: the continuous deterioration in the security file and the scale of sabotage operations of infrastructure, high levels of financial and administrative corruption among the senior state employees, also production of many domestic products has stopped, and reliance on the import that caused raise the record of price index of goods in the domestic market to international levels. The Central Bank of Libya (2008) conducted a study to identify the sources of inflation in the 
Libyan economy during the period (1980-2007). This study reached a number of results, the most important of which are: The reasons for inflation in the Libyan economy include high demand, excessive cash, high production costs, Especially with regard to the exchange rate of the Libyan dinar, in addition to the procedures adopted in relation to the amendment of the prevailing legislation for the exercise of economic activity and its instability, all that led to higher prices of some goods and lower prices of others, in order to contradict the objectives of these procedures The short term as protect the local product and reduce individuals' living costs. As for, the study of Al Khathlan (2011), where this study was applied in Saudi Arabia and aims to identify the determinants of inflation in the long term as well as in the short term, using the method of joint integration. Where the results of this study show that the devaluation of local currency and supply bottlenecks are the main factors affecting long-term inflation. As for, in the short term, cash supply bottlenecks were found to represent the main factors affecting inflation in the country. Amer (2014), This study was conducted in Algeria to determine the central bank's role in tackling inflation. The study concluded that the central bank made several reforms, notably the Monetary and Credit Law, which gave the central bank greater independence and authority in using and directing its tools to tackle inflation. As for, Lim and Sek (2015), their study aimed to identify the factors affecting inflation in two groups of countries (high inflation group and low inflation group). The results of this study indicate that GDP growth and imports of goods and services have a long-term impact on inflation in low-inflation countries. The results of this study also show that monetary supply, national expenditure, and GDP growth are determinants of inflation and have a long-term impact on inflation in high-inflation countries. As for, in the short term, there are no variables to be significant determinants in high inflation countries. However, money supply, commodity imports, services and GDP growth have a significant relationship with inflation in low-inflation countries.

\section{Definition of inflation:}

Erekat \& Abdu alrahman (2004) defined Inflation as the continuous increase in the overall price level, which leads to a decrease in the purchasing power of money, resulting in economic and social problems. As for Al-Rubaie (2006), defined Inflation as the general and continuous rise in the overall level of prices, and this does not mean that the rise is in all prices, but the general trend must be upward and because of the policy-making process. But if the price increases only once, there is no need for policymaking, where after a period of adaptation, but in inflationary conditions, prices are increasing indefinitely, and there will be a need for making policies. Also,

Alnosur (2013) define the inflation as an economic situation in which the purchasing power of the monetary unit weakens due to the high prices to high levels. As a result, the turnover of money increases and the function of money is lost as a store of value and becoming the role of money only as an intermediary for exchange.

\section{Types of inflation:}

Alafi \& Said (2016) pointed to types of inflation that can be distinguished as: the first is moderate inflation or creeping inflation, which is a moderate and simple increase in the general price level, which does not exceed 10\% per year. The second is known as hyperinflation, which is a continuous rise in prices with a high rate exceeding $10 \%$ and in close periods of time. Also, there are different types of inflation attributed to a variety of reasons such as:

$>$ Demand inflation: due to the increase in aggregate demand for aggregate supply, leading to a general rise in prices.

$>$ Cost inflation: this is due to the high costs of production elements, which lead to a continuous rise in the prices of goods and services produced.

$>$ Imported inflation: Moves through imported goods and services, especially when the country is heavily dependent on imports and when the exporting country is suffering from inflation. 
> Common inflation: this is caused by the increase in purchasing power and the volume of liquidity of individuals, while the volume of total output of goods and services remains constant, leading to a rise in aggregate demand while the overall supply remains stable.

\section{Methods of measuring inflation:}

To measuring Inflation, we can use the standard figure of prices where indicated to relative averages showing the evolution of money and prices for goods and services and based on the use of a benchmark called the base year. The most important the standard figure of prices that represented as follows Hassis (2016):

$>$ Consumer price index: Used to identify the effect of price changes on the purchasing power of the consumer, rather than measuring the general rate of price increase.

$>$ The standard figure to the prices of the product: is a measure that shows the prices of the basic commodities, provided that the representative for the family sector request.

$>$ The implicit standard figure of prices that uses to exclude the effect of the change in price level. where GNP reflects the market value of goods and services divided on a real national product at constant prices to detect price variance and inflation.

Inflation can also be measured by calculating the inflationary gap, which is one of the criteria that determine the reasons for price changes. The analysis of the inflationary gap depends on identifying the surplus demand in commodity markets, without taking into account the excessive demand in the markets of factors of production. The most important criteria used to measure the inflationary gap are: Total surplus demand criterion - surplus money supply criterion - standard of monetary stability coefficient.

\section{Means of treatment of inflation:}

Inflation can be tackled by means of reducing the aggregate demand that puts pressure on the markets of goods and services or limits their growth and the most important of these means Erekat \& Abdu alrahman (2004):

$>$ Public expenditure reduction: This policy aims to reduce expenditure, whether government spending or private sector spending.

$>$ Money supply: This policy is practiced by the central bank, which reduces money supply in order to limit its growth.

$>$ Payment of taxes: This policy aims at the competence of purchasing power in the society by raising the tax rates which are amounts deducted from the income, whether directly or indirectly.

Loans: Countries may resort to borrowing from the private sector for the purpose of combating inflation, and often resort to this when not enough means to eliminate inflation. In general, to combat inflation, economic policy as the tools of financial policy and monetary policy instruments is usually used. Where the financial policy instruments used to achieve economic stability are government spending and taxes. Monetary policy uses the offer of money as an influence on economic activity, raising interest rates by open market policy. Thus, total expenditure is reduced until the emerging inflation gap is addressed by increasing the aggregate demand for aggregate supply, also monetary and monetary policies can be combined to treat inflation.

\section{Effects of inflation:}

The most prominent effects of inflation include Al-Rubaie (2006):

$>$ Loss of money for its functions, especially its function as a measure and store of value.

$>$ Redistribution of national income among the strata of society in favour of changeful income.

$>$ Redistribution of national wealth among the layers of society and in a random way.

$>$ The abandonment of the national currency and the recourse to a foreign currency is more stable in value. 
Inflation quickly leads to a rise in the balance of payments deficit as a result of the local industry being subjected to intense competition from abroad, increased demand for imported goods and reduced demand for domestic goods.

\section{Brief overview of inflation in Libya:}

Inflation is not a new phenomenon on the Libyan economy and it can be said that it has existed in the Libyan economy since the seventies, especially after the rise in oil prices globally, also through the period of siege until the financial crisis witnessed by the world in 2008. Where the Central Bank of Libya (2008) conducted a study on inflation during the period (1980 to 2007), where the annual growth rate of inflation according to that study was $15.8 \%$. The study indicates that part of this inflation is due to a combination of local factors, that directly contributed to a real imbalance between the cash flow stream and the real supply stream of goods and services. The other part of these inflationary pressures was attributed to inflation imported from international markets due to the dependence of the Libyan economy on the outside world in meeting the supply deficit of goods and services through Demand for imports of goods and services. As for the period before the events of 2011, the Central Bank of Libya (2013) pointed to a significant rise in inflation rates during 2008, which amounted to $10.4 \%$, due to a number of factors, the most important of which are the rise in import prices due to the inflationary trend witnessed by the global economy due to the increase in oil prices, where money supply is growing at a steady rate through increased public spending.

\section{The annual growth rate of inflation in Libya:}

Inflation is measured by the price index, which shows the relative changes in the prices of selected goods and services that represent consumer spending over a specified period of time. To analyze the growth rate of annual inflation in Libya during the period (2011 - 2018), we have adopted on the consumer price index is an important indicator used to measure changes in the overall level of prices. Thus, it is possible to judge the success of the economic policies implemented in maintaining the purchasing power of the monetary unit. Moreover, the increase in the price index indicates a decrease in the purchasing power of money and a decrease in the consumer's ability to access goods and services. In order to determine the evolution of price movements and inflation rates in Libya during the period (2011-2018), the data of standard figure for consumer prices was adopted for $(2003)$ as a base year $(2003=100)$.

Table (1) Consumer Price Index

A base year $(2003=100)$

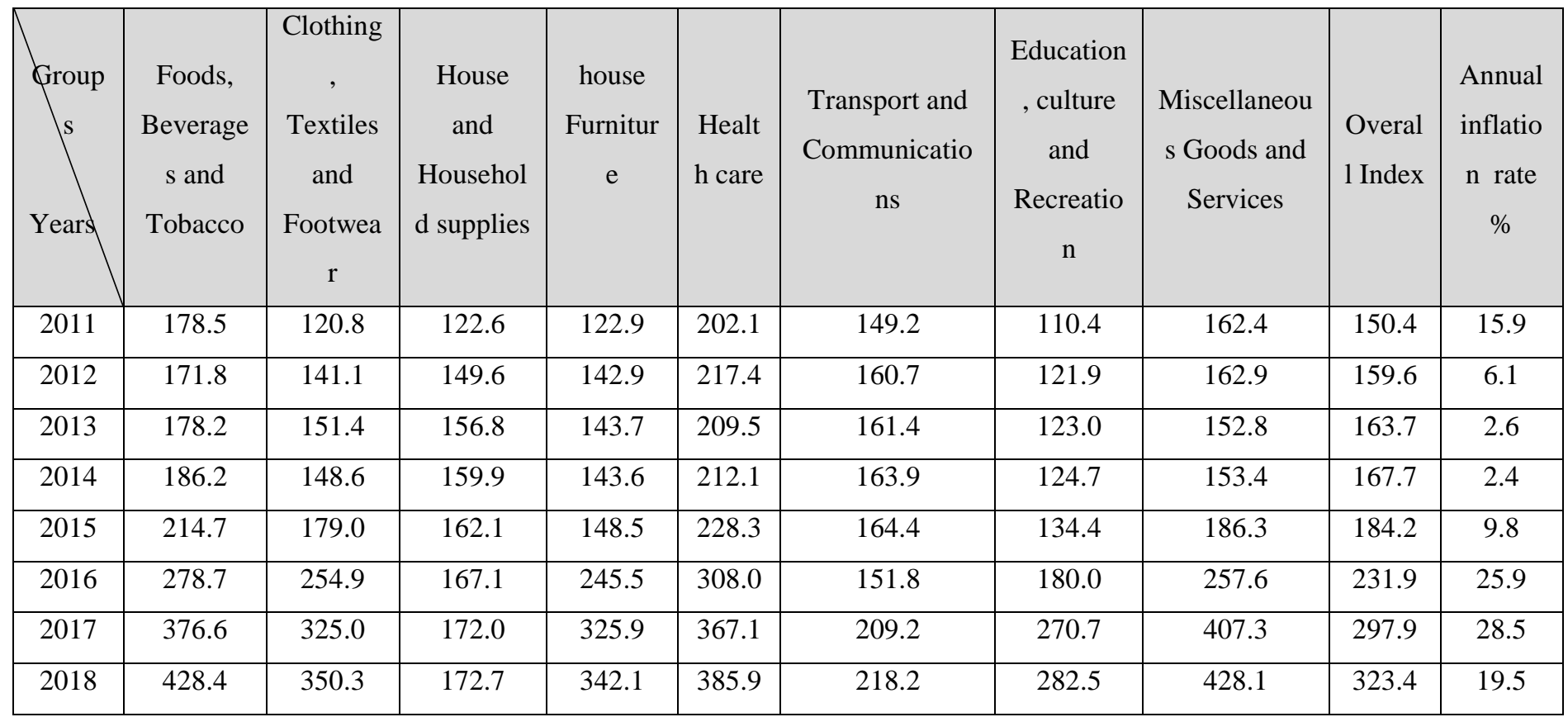

Source: Preparation of the researcher based on the data of the economic bulletin (2018). 
The figures in the table above show that the increase in the general index was accompanied by a rise in all components of the consumer price index and that the increase was not limited to the prices of some commodities, indicating an increase in the general price level. The table shows that the general index of consumer prices continued to rise from (150.4)in 2011 to (323.4)in 2018 , where the rate of increase $(9.2,4.1,4,16.5,47.7,66,25.5)$ respectively. The following figure shows the rise in the general index of consumer prices during the period (2011-2018).

Figure (1) the rise in the general index of consumer prices during the period (2011-2018).

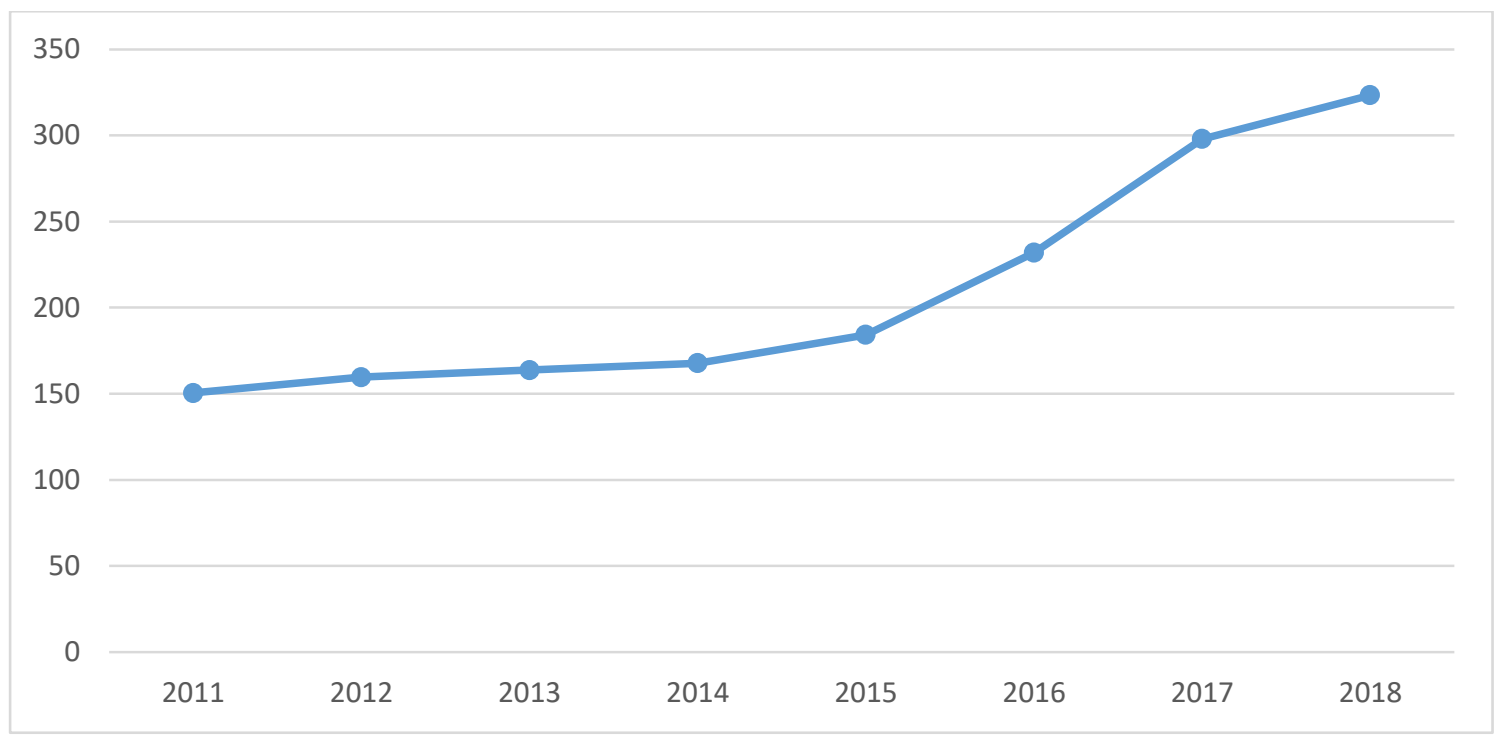

Source: Preparation of the researcher based on the data of the economic bulletin (2018).

Also, from the table above we can show a steady increase in the annual rate of inflation during the year 2011, which reached 15.9\%. As a result of the beginning of the revolution events in Libya, and during the years (2012, 2013, 2014), we find that there is a kind of stability in Libya, where the inflation rate fell from 15.9\% during in 2011 to $2.4 \%$ during the year 2014. But annual rate of inflation rose again in the year 2015 to $9.8 \%$, and continued to rise strongly, reaching $28.5 \%$ during the year 2017 , as a result the cessation of many oil fields because of conflict on the oil fields by armed groups to seize them, where oil is the main source of income in Libya, where with stopping production and export of oil has led to a decline in the value of the local currency against foreign currencies, which led to a shortage the supply of all goods and services. In addition to the increase in public spending as a result of the adoption of the budget that is considered the highest in the history of Libya, which resulted in a significant increase in current spending rates. With the end of 2017, some oil fields began production again, but at rates lower than before the revolution, which led to a relative decrease in inflation, where reaching at the end of 2018 to $19.5 \%$. The following figure shows the annual inflation rate in Libya during the period (2011-2018). The following figure shows the annual inflation rate in Libya during the period (2011-2018). 
Figure (2) the annual inflation rate in Libya during the period (2011-2018).

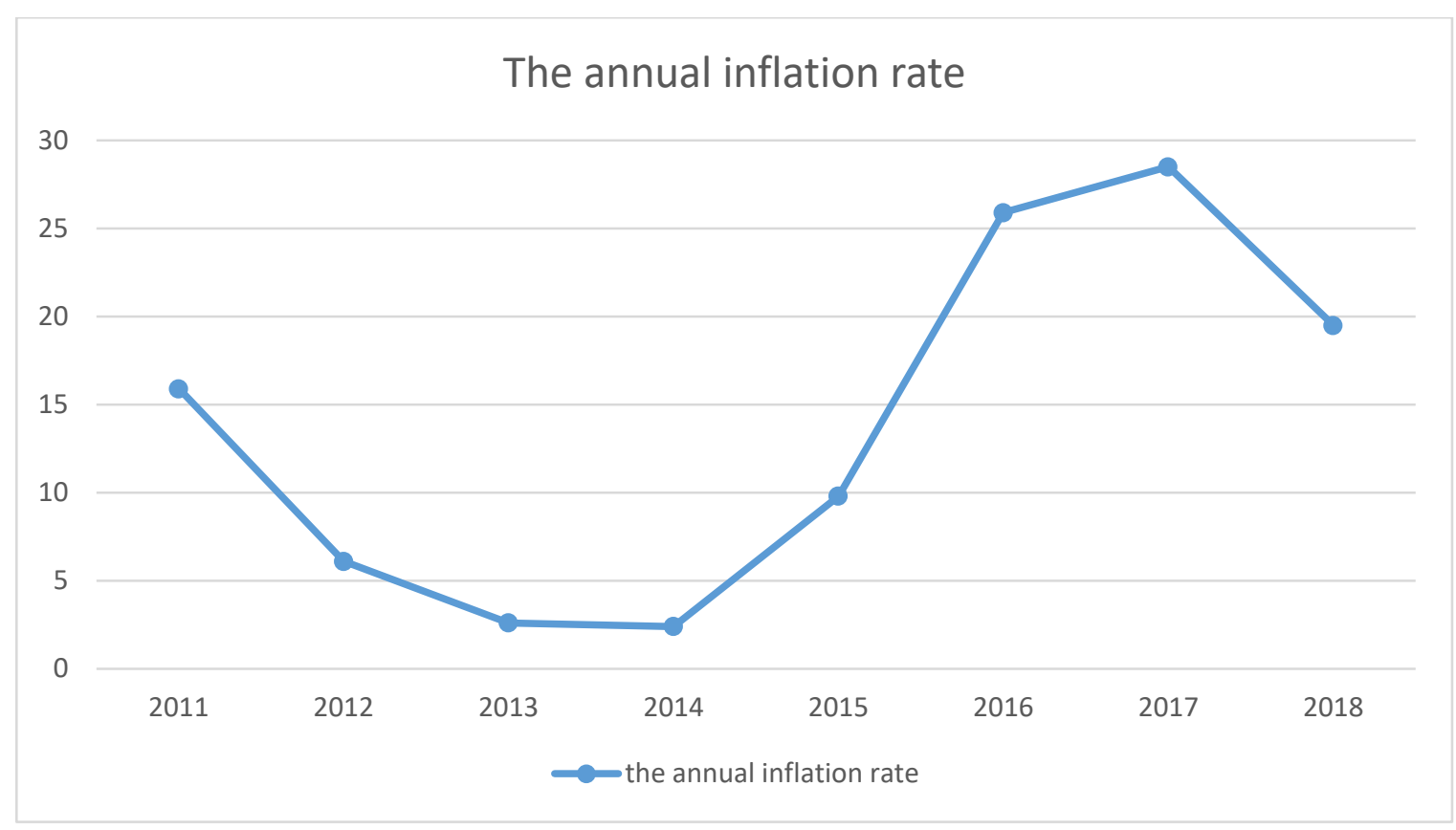

Source: Preparation of the researcher based on the data of the economic bulletin (2018).

\section{The effects of inflation on the Libyan Economy:}

The successive rises in domestic price levels and the accompanying decrease in purchasing power of the monetary unit affect the various economic and social aspects. Where Inflation also plays an important role in the redistribution of national income in the community for the benefit of the owners and producers of productive projects at the expense of limited- Income people, in addition to the impact of inflation on the balance of payments and the movement of investments in the national economy, and the most important economic indicators that affected by inflation, as the following:

\subsection{Impact of inflation on deposits with the Libyan banking system:}

The effect of inflation on deposits at banks can be studied that through studying and analyzing the development of deposits of individuals and institutions at banks and their ratio to total money supply during the period (2011-2018). 


\section{Table (2): Development of deposits with banks and their ratio to total money supply during the period (2011-2018)}

In millions of LYD.

\begin{tabular}{|c|c|c|c|c|c|c|}
\hline \multirow{2}{*}{ Years } & demand & \multirow{2}{*}{ Time deposits } & Saving & Total \\
& deposits & & Teposits \\
Deposits & Total money & $\begin{array}{c}\text { Toposits } \\
\text { supply }\end{array}$ & $\begin{array}{c}\text { to total } \\
\text { money } \\
\text { supply\% }\end{array}$ \\
\hline 2011 & $38,597.0$ & $3,819.9$ & 683.9 & $43,100.8$ & $57,305.9$ & 75 \\
\hline 2012 & $45,822.6$ & $3,812.5$ & 705.3 & $50,340.4$ & $63,731.5$ & 79 \\
\hline 2013 & $50,879.5$ & $4,043.6$ & 662.9 & $55,586.0$ & $69,005.9$ & 81 \\
\hline 2014 & $49,497.7$ & $2,078.0$ & 603.0 & $52,178.7$ & $69,404.7$ & 75 \\
\hline 2015 & $58,725.9$ & $11,956.7$ & 574.5 & $71,257.1$ & $78,606.3$ & 91 \\
\hline 2016 & $72,192.7$ & $10,644.7$ & 570.2 & $83,407.6$ & $96,320.9$ & 87 \\
\hline 2018 & $84,827.6$ & $10,519.2$ & 591.7 & $95,938.5$ & $111,338.7$ & 86 \\
\hline
\end{tabular}

Source: Preparation of the researcher based on the data of the economic bulletin (2018).

The previous table shows that deposits of individuals and institutions with the banking system increased from $(43,100.8)$ million of LYD in 2011 to $(95,938.5)$ million of LYD in 2017. Despite the increase in the value of deposits with the banking system, but their ratio to total money supply declined during the period $(2011-2018)$ with $(75 \%, 79 \%, 81 \%, 75 \%, 91 \%, 87 \%, 86 \%, 85 \%)$ respectively, that indicating to a decline of individual confidence in monetary policies due to the rise in annual inflation rates, that lead to increasing the tendency of individuals to withdraw their savings from the banks, contributing to the payment of local prices towards to rise.

\subsection{The impact of inflation on the Libyan of payments balance:}

In view of the difficulties facing the export process, while increasing the dependence of the national economy on imports, inflation will have a significant impact on the balance of payments. Inflation will also lead to the outflow of national capital abroad and the weak ability of the national economy to attract foreign investments. Thus, the deficit of the balance of payments is increased. Where the Libyan economy is characterized by a small economy and open to the outside, which greatly increases the impact on the balance of payments, especially in light of the increases in imports, with the decline in exports and the deterioration in the local currency value. Where the balance of payments deficit during the years 2013-2014 -2015 -2016 reached (-10.9\%, $63.7 \%,-67.2 \%,-45.5 \%)$, respectively.

\subsection{Impact of inflation on Libyan imports:}

The Libyan economy depends on the global economy almost entirely in terms of importing all its consumer and investment goods, where a large proportion of the expenditure in Libya goes to consume imported goods. Data from the Central Bank of Libya (2018) indicate that the value of imports of goods and services increased during 2011 from 13,664.0 to 38,631.7 billion dinars in 2014, then the value of imports decline during in 2015 to 22,684.5 billion dinars, and continued to decline to $12,047.0$ in 2016, then increased again during in 2017 amounted to 14.673 billion dinars. The decline in the external value of the local 
currency is somewhat consistent with the increase in the value of imports from goods and services during the period 2011-2017, which was reflected on the rise in the general level of the prices of goods.

\subsection{Impact of inflation on Libyan exports:}

The Libyan economy relies on oil exports to finance the state budget, as well as considered the main source of income in Libya. Therefore, the events that took place in Libya after the revolution led to a decrease in the production and export of oil in the country where exports decreased from 76,893.0 billion dinars in 2012 to 26,221.7 billion dinars in 2017. Thus, inflation led to higher prices of Libyan exports and reduced their competitiveness in the international market.

\subsection{The impact of inflation on the exchange rate of the Libyan dinar:}

Inflation has a direct impact on the exchange rate of the national currency (dinar), through the decline in purchasing power in light of the rise in domestic prices. The increase in domestic demand for foreign currencies to finance imports of goods and services creates surplus in the demand for foreign currency, which is reflected in the form of a decline in the purchasing power of the national currency against foreign currencies. The exchange market in Libya is divided according to the exchange rate mechanism in two markets: the official exchange market. Where the central bank determines the official exchange rate of the Libyan dinar against foreign currencies. Where the Libyan dinar has ranged between 1.25 and 1.33 dinars per dollar during the past five years. In the parallel exchange market, the value of the national currency against other foreign currencies is determined in accordance with the forces of supply and demand for foreign exchange. Where the exchange rate in the parallel market has started to take an upward and gradual course with the increasing demand for foreign exchange for various reasons coupled with difficulty getting it from the banking system, where reached about 8 dinars per dollar, which generated inflationary waves in the country (Alafi \& Said, 2016).

\subsection{The impact of inflation on the state budget:}

It is economically known that the tools of fiscal policy, that represented in spending, borrowing, and taxation, where the effectiveness of tools lies in periods of inflation by reducing public expenditure and increasing the proceeds of tax revenues. Through table (3), we can find that, after the revolution in Libya, public revenues fell from 70.131 .4 billion dinars in 2012 to 16,705.4 billion Libyan dinars in 2018. This decline is due to political unrest in Libya, and the continued stopped of the oil sector from production, where its revenues faded because of the production stopped. 


\section{Table (3): Actual revenues and expenditure during the period (2011-2018)}

In millions of LYD.

\begin{tabular}{|c|c|c|c|c|c|c|c|c|}
\hline \multirow[b]{2}{*}{ Years } & \multicolumn{3}{|c|}{ Public Revenues } & \multicolumn{5}{|c|}{ Public Expenditures } \\
\hline & $\begin{array}{c}\text { Oil } \\
\text { Revenues }\end{array}$ & $\begin{array}{l}\text { Non- Oil } \\
\text { Revenues }\end{array}$ & Total & $\begin{array}{l}\text { Administrative } \\
\text { Expenditures }\end{array}$ & $\begin{array}{l}\text { Development } \\
\text { Expenditures }\end{array}$ & $\begin{array}{l}\text { Subsidies } \\
\text { and price } \\
\text { stabilization }\end{array}$ & $\begin{array}{c}\text { Extra } \\
\text { Budget }\end{array}$ & Total \\
\hline 2011 & $15,830.1$ & 983.2 & $16,813.3$ & $17,850.1$ & 0.0 & $4,414.4$ & $1,372.0$ & $23,366.5$ \\
\hline 2012 & $66,932.3$ & $3,199.1$ & $70,131.4$ & $36,733.0$ & $5,500.0$ & $11,708.6$ & - & $53,941.6$ \\
\hline 2013 & $51,775.7$ & $2,987.9$ & $54,763.6$ & $42,598.5$ & $13,276.5$ & $9,408.5$ & - & $65,283.5$ \\
\hline 2014 & $19,976.6$ & $1,566.7$ & $21,543.3$ & $26,892.0$ & $4,482.4$ & $12,439.8$ & - & $43,814.2$ \\
\hline 2015 & $10,597.7$ & $6,245.7$ & $16,843.4$ & $23,933.1$ & $3,861.9$ & $8,219.9$ & - & $36,014.9$ \\
\hline 2016 & $6,665.5$ & $1,929.7$ & $8,595.2$ & $21,315.8$ & $1,398.3$ & $5,723.8$ & 350.0 & $28,788.4$ \\
\hline 2017 & $19,209.0$ & $3,128.6$ & $22,337.6$ & $24,834.4$ & $1,887.6$ & $5,970.0$ & - & $32,692.0$ \\
\hline 2018 & $15,605.4$ & $1,100.0$ & $16,705.4$ & $13,018.3$ & 651.6 & $3,227.1$ & - & $16,897.0$ \\
\hline
\end{tabular}

Source: Preparation of the researcher based on the data of the economic bulletin (2018).

As for public expenditure, there is a decrease in public expenditure from (65,283.5) billion dinars in 2013 to (16897.0) billion dinars in 2018. The drop in public spending was due to measures taken by the government authorities, which included a reduction in expenditure from $(13,276.5)$ in 2013 to (651.6) billion dinars in 2018. Where t1he public expenditure inflation exacerbated the deficit in the state budget, especially as the structure of the public spending deficit changed in favor of current expenditure at the expense of development spending. Where the balance of payments deficit worsened during the period (2013-2018) due to the decline in oil production and exports due to the general situation in Libya, which led to the closure of oil export ports, as well as low capacity to mobilize any alternative financial resources.

\section{Conclusions:}

- The estimates for the figures standard indicate that there has been an increase in the general level of prices about $50 \%$ over the last five years. This increase was accompanied by an increase in all components of the consumer price index, and not limited to the prices of some goods.

- There is a steady increase in the annual rate of inflation during the year 2011 as a result of the beginning of the revolution events in Libya. Then inflation continued to rise strongly because of conflict on the oil fields by armed groups to seize them, which led to a shortage of the supply of all goods and services.

- Despite the increase in the value of deposits of individuals and institutions with the banking system, however, their ratio to total money supply decreased. That indicates an increase in the tendency of individuals to withdraw their savings from banks, that caused to raise the level of domestic prices.

- Higher imports of goods and services, in contrast, the value of oil exports declined, indicating that the decline in the external value of the local currency is consistent with the increase in the value of imports of goods and services.

- The crisis in Libya cased to close the ports of oil export, in addition, the decline in oil prices worldwide, led to a significant decline in public revenues accompanied by a deficit in the state budget. 


\section{Recommendations:}

- Strengthen cooperation between the legislative and executive authorities in order to formulate economic policies aimed at combating inflation.

- Rationalizing consumer spending and reducing dependence on oil revenues by activating the tools of fiscal policy such as tax policy.

- Adopting real structural reforms in order to eliminate dependency to abroad and eliminate all manifestations of economic backwardness.

- $\quad$ Take some measures that will restore confidence between depositors and the banking system.

\section{References:}

- $\quad$ Alafi, A.A., \& Said, M.M. (2016). The impact of fiscal and monetary policies on the inflation rates in Libyan economy during period of 2010 - 2014. Seminar on: The economic and financial crisis in the Libyan economy: challenges and reform policies required, University of Sebha. Pp:42-62.

- Al Khathlan, K. (2011). Inflation in the Kingdom of Saudi Arabia: The bound test analysis. African Journal of Business Management Vol. 5(24), pp. 10156-10162, 14.

- Alnosur, E.A. (2013). The Basics of Macroeconomics, First Edition, Amman: Dar Al Safa Publishing.

- Al-Rubaie, F.K. (2006). Explanation of inflation in the Iraqi economy, inflation seminar entitled: Inflation and the role of financial and economic policies, Iraq's Journal of Economic Reform, No. 3, PP:26.-25.

- Amer.D.(2014). Evaluation of the role of the Central Bank in tackling inflation Algeria case study - 2009 to 2014. unpublished master thesis. University Echahid Hamma Lakhdar. Algeria.

- Central Bank of Libya (2008), the phenomenon of inflation in Libya, management of research and statistics.

- Central Bank of Libya (2013). Fifty-seventh Annual Report. Research and Statistics Administration.

- Central Bank of Libya (2018). Economic Bulletin. second quarter. Volume 58, Research and Statistics Administration.

- $\quad$ Erekat, H, \& Abdu alrahman, I. (2004). Concepts of Economic Systems, First Edition, Amman: Dar Wael Publishing.

- Hassis. (2016). The rate of inflation in Algeria between the reality and the theory during the period (2001 - 2015). unpublished master thesis, University of Oum El-Bouaghi, Algeria.

- $\quad$ Lim, Y.C; \& Sek, S.K. (2015). An Examination on the Determinants of Inflation. Journal of Economics, Business and Management, Vol. 3, No.7. 